\title{
Natural Distribution of Nauclea diderrichii (Rubiceae) in Semi Deciduous Forest of Togo (West Africa) and Implementation of Integrated Silviculture
}

\author{
Kossi Adjonou', Yaovi Nuto², Paul P. Bosu³, Stephen Adu-Bredu³, Adzo Dzifa Kokutse', \\ Kouami Kokou ${ }^{*}$ \\ ${ }^{1}$ Laboratoire de Botanique et Ecologie Végétale, Faculté des Sciences, Université de Lomé, Lomé, Togo \\ ${ }^{2}$ Département de Zoologie, Faculté des Sciences, Université de Lomé, Lomé, Togo \\ ${ }^{3}$ Forest Research Institute of Ghana (FORIG), Kumasi, Ghana \\ Email: "kokoukouami@hotmail.com
}

Received 24 January 2014; revised 9 March 2014; accepted 22 March 2014

Copyright (C) 2014 by authors and Scientific Research Publishing Inc.

This work is licensed under the Creative Commons Attribution International License (CC BY).

http://creativecommons.org/licenses/by/4.0/

(c) (i) Open Access

\begin{abstract}
West African tropical forests spread from Senegal to Togo. They are considered as one of the world biodiversity hotspots. But these forests are disappearing very quickly because of human activities. In Togo, tropical forests degradation has been increased since 1980 because of improved coffee cultivation; about $67 \%$ of forests in the sub-humid mountains zone disappeared between 1978 and 2000. Facing this fast deterioration of the forests, populations begin to plant teak (an exotic species) that is the only choice proposed by local forest service. This survey consists in valuing the potentialities to restore the Togolese tropical forest using the local commercial species, recognized on the wood market. The first species retained is Nauclea diderrichii (De Wild. \& Th. Dur.) Merrill, that spreads in the African tropical forest from the Sierra Leonne to Uganda and through the Congo basin. In Togo, this plant species colonises the plain of the Litimé. The objective of the present study is to analyze the distribution of the natural populations in the plain of Litimé forest but also natural and artificial regeneration of the species. The perspective is to repeat this experiment with other local species in other regions of Togo in order to diversify the plantations and to protect the local forest biodiversity.
\end{abstract}

\section{Keywords}

Litimé; Tropical Forests; Degradation; Biodiversity; Nauclea diderrichii (De Wild. \& Th. Dur.)

\footnotetext{
*Corresponding author.
}

How to cite this paper: Adjonou, K., et al. (2014) Natural Distribution of Nauclea diderrichii (Rubiceae) in Semi Deciduous Forest of Togo (West Africa) and Implementation of Integrated Silviculture. American Journal of Plant Sciences, 5, $1220-$ 1235. http://dx.doi.org/10.4236/ajps.2014.59135 


\section{Merrill}

\section{Introduction}

The extinction of the tropical forest is recorded everywhere throughout African continent. [1] and [2] reported that in Nigeria, the annual rate of deforestation was 285.000 ha/year between 1976 and 1980 and increased to 400.000 ha/year in the 1990s. In Cameroon, more than 200,000 ha of rainforests have been degraded over the recent years because of logging [3]. In Togo, the extinction of forests had been manifest in the 1980s when agriculture in the forest zone was directed towards the farming of improved coffee plant. Contrary to the non-improved coffee that was traditionally grown in the forest undergrowth, the improved coffee plant grows well in open areas. Because of the new constraints of production, the rainforests in the sub-humid mountainous zone of Togo [4]-[6] underwent significant reductions; about 67\% were lost between 1978 and 2000 i.e. an annual rate of 3\% [7] [8]. Today, the remains of these forests are located along rivers [9] or at the slopes and difficult to access.

Faced with the rapid degradation of semi-deciduous forests of the mountains of Togo [4]-[6] considered as one of the hotspots of biodiversity [10], the reaction of the populations, regretful of past times when they were surrounded by forests, has started planting, especially with exotic species including teak (Tectona grandis). However, in this zone there are indigenous species that can contribute significantly to the forests restoration. Among the value timber species are Entandrophragma angolense, Khaya grandifoliola, Mansonia altissima, Milicia excelsa, Nauclea diderrichii, Terminalia spp. Scleroxylon Triplochiton, etc. which can widely be used in reforestation. In some neighbouring countries such as Nigeria, Ghana or Côte d'Ivoire, studies have been undertaken since the beginning of the 20th century to use these species in plantations [11]. Unfortunately, information about their ecology, their silviculture and their slow growth compared to exotic species does not encourage their use in forest plantation. However, faced with the loss of biodiversity through the excessive use of exotic plants in plantation and the high demand of indigenous species on the timber market, an effort must be done. It is in this framework that the African Academy of Sciences (AAS), in French Académie Africaine des Sciences (AAS), funded the project on "Biology, impact and integrated management of the Opepe (Nauclea diderrichii) Shoot Borer (Orgymophora mediofoveata, Lepidoptera: Noctuidae) in West Africaed” in Ghana and in Togo. Nauclea diderrichii (Nd) is a commercial value species present in the African tropical forest from Sierra Leone to Uganda through Central Africa and some parts of East Africa [12]. In Togo, it is preferably found in the Litimé plain (Figure 1). The timber, very resistant to decay, borers and termites, is used in heavy construction, in furniture, plywood and many other domestic uses. This species is classified together with iroko and mahogany. In some countries of the sub-region such as Ghana and Nigeria, it is one of the five local priority species used in plantations. [13] [14] reported that in Nigeria, Nd is the indigenous species of which the plantations are more numerous and the most successful in the supply of timber and electric poles. The species is already well known and highly appreciated by local people for its durability and the aesthetics nature of its wood.

The main objective of this paper is to assess the potential of the species in monoculture or joint farming in Togo. This study presents, more specifically, the works carried out on natural stands, the regeneration capacity and the growth of the species, a fundamental approach to the formulation of strategies of Nd integrated silviculture in Togo. It is about knowing the spatial distribution and the structure of Nd natural populations, the appropriate regeneration mode, the environmental factors promoting the growth and the adaptation of the plant to other ecosystems different from those of semi-deciduous forests of Litimé where the natural stands have been identified for the first time in Togo. Regarding the growth of the species and the control of its silviculture, the research question is to know the Nd behaviour in pure stand or in combination with commercial timber species.

\section{Materials and Methods}

\subsection{Materials}

\subsubsection{Study Area of Nd Natural Stands}

Litimé is located in zone IV, semi-deciduous forests domain [4]. It is part of the Volta River Basin, located on the western foothills of Akposso and Akébou plateaux. It is an area wedged between the plateau and the Buem 


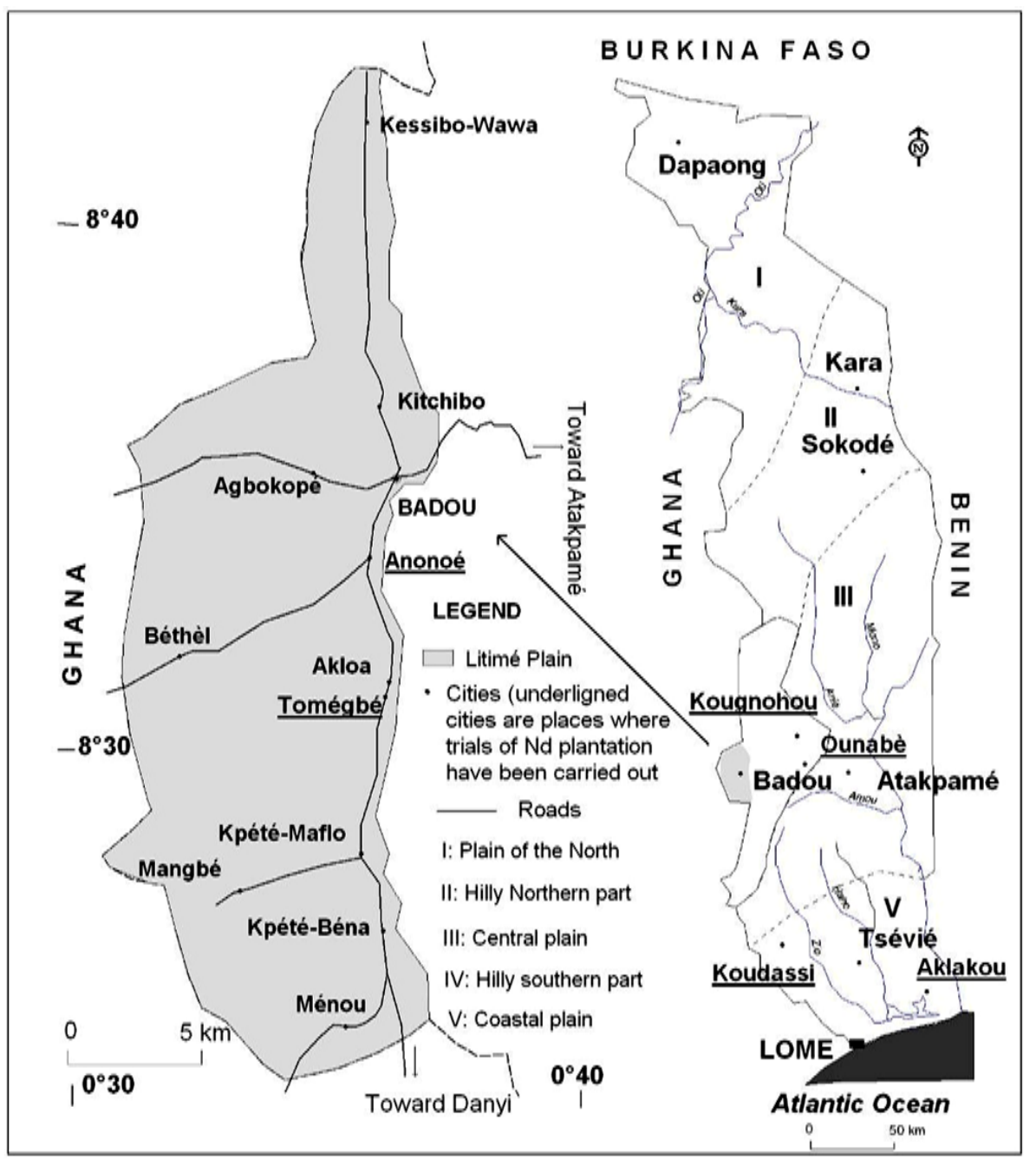

Figure 1. Map reference of Litimé plain and Nd growing sites experiment.

on the Ghana side with which it shares the southern, western and north-westen border over more than $50 \mathrm{~km}$. It is almost a plain that stretches between $70^{\circ} 20^{\prime}$ and $8^{\circ}$ north latitude (Figure 1). It covers a surface of approximately $500 \mathrm{~km}^{2}$, i.e. $10 \%$ of the forest zone of Togo [4]. With an altitude around $200 \mathrm{~m}$, it is tilted to the west and is as such, the basin side of a chain of inland hills. Between these hills, and the escarpments of Akposso and Akébou plateaux small plains and benches come into contact. The escarpment that separates this zone and plateaux has a vertical drop of 300 meters. This hillside is heavily cut by many valleys where streams flow through areas that form waterfalls. The geological substrate is composed of shale-intercalated quartzite. The disintegration of these materials results into the formation of ferrallitic soils. At the escarpments level, come into contact lithosoils while the least developed soils from alluvial inputs are brought by rivers. A final type of soils is made up of tropical ferruginous soils and hydromorphic soils from flood plain.

The climate is of the transitional subequatorial type [15] but the specificity of Litimé is the effect of the relief layout. The western escarpment of the Atacora chain constitutes a real front causing the rise of the hot and humid air of the atlantic monsoon. This rise favours the air-cooling that results in water steam condensation, consequently increasing the local rainfall. With an annual cumulative rainfall close to $1500 \mathrm{~mm}$, the Litimé plain is part of the most humid regions of Togo. September is the wettest month $(240.9 \mathrm{~m})$ and January is the driest (101 $\mathrm{mm})$. The monthly average temperatures are generally high and vary between $21^{\circ} \mathrm{C}$ and $28^{\circ} \mathrm{C}$. The hottest moments of the year range from February to April and the coolest from July to September. The moisture associated with the existence of forests constitutes a regulating effect of the prevailing heat. The annual thermal amplitude is low and is around $6^{\circ} \mathrm{C}$. Unlike the latter, the daily temperature variation is significant and can rise up to $16^{\circ} \mathrm{C}$. 
The annual average temperature is close to $25^{\circ} \mathrm{C}$ and is one of the characteristics of the warm climate [16].

The Akposso are the indigenous people living in the Litimé plain. The farming labour demand has resulted into a series of populations' migration from the north (Kabyè, Nawdeba, Cotocoli and Lamba). The density is about 80 inhabitants $/ \mathrm{km}^{2}$.

\subsubsection{Data Collection}

The study consisted of a general survey of natural living communities of $\mathrm{Nd}$ in the Litimé plain. Three teams of 4 to 5 researchers and technicians, equipped with GPS ran through the forest on foot to identify and measure trees $\mathrm{dbh} \geq 10 \mathrm{~cm}$ or $0.25 \mathrm{~m}$ wide from coppices on live stumps, the total height and the merchantable height. The diameter is measured with DBH tape while the heights of trees are measured with the relascope of Bitterlich. In total 1926 ha have been covered and demarcated by using GPS during a random sampling. The dead or live stumps of felled trees are also taken into account. In the latter case, the number of coppices is counted by stump.

To characterize the ecology of trees, a sheet of ecologic descriptors is filled each time a stem of Nd is encountered. This description relates to the topography, soil texture, the flooding state, the vegetation type, the layers recovery and the surrounding human activities.

From October to February, the seed trees bear fruits. Fruits were harvested for germination tests and the monitoring of the nursery plant. The extraction is carried out by soaking the fruit in water to extract the seeds that are very small. Dried for 24 hours in ambient air, they were planted 10 days later in germinators. The removal of seedlings from the germinating tank occurs between 10 and 21 days in average. Transplanted in bags, it took about three months to get the seedlings ready to plant (Photo 1). The experimental work for the silviculture test was conducted over a period of 18 months.

The seedlings obtained were planted in the experimental station of the "Institut Togolais de Recherche Agronomique" (ITRA) of Tomégbé ( $7^{\circ} 30^{\prime} 36 " \mathrm{~N}, 0^{\circ} 36^{\prime} 14^{\prime \prime E}$; rainfall $1500 \mathrm{~mm} /$ year; ferrallitic soil on mother rock, semi-deciduous forest) in the Litimé. The experimental layout consists of 12 plots of $24 \mathrm{~m}$ long and $6 \mathrm{~m}$ in width or $144 \mathrm{~m}^{2}$ of surface. The plots are grouped into 4 randomized blocks of 3 plots. The first block is planted in pure $\mathrm{Nd}$, the 2nd $\mathrm{Nd}$ in association with Terminalia superba (Ts), a competitor tree of the high stratum of semideciduous forests of Litimé, the 3rd Nd in association with Garcinia afzelii (Ga), a shrub of the undergrowth and the 4th Nd in association with Ts and Ga. Each plot contained 36 plants. The measurements were performed every 6 months for 18 months and consisted of measuring the height of plants and counting the dead

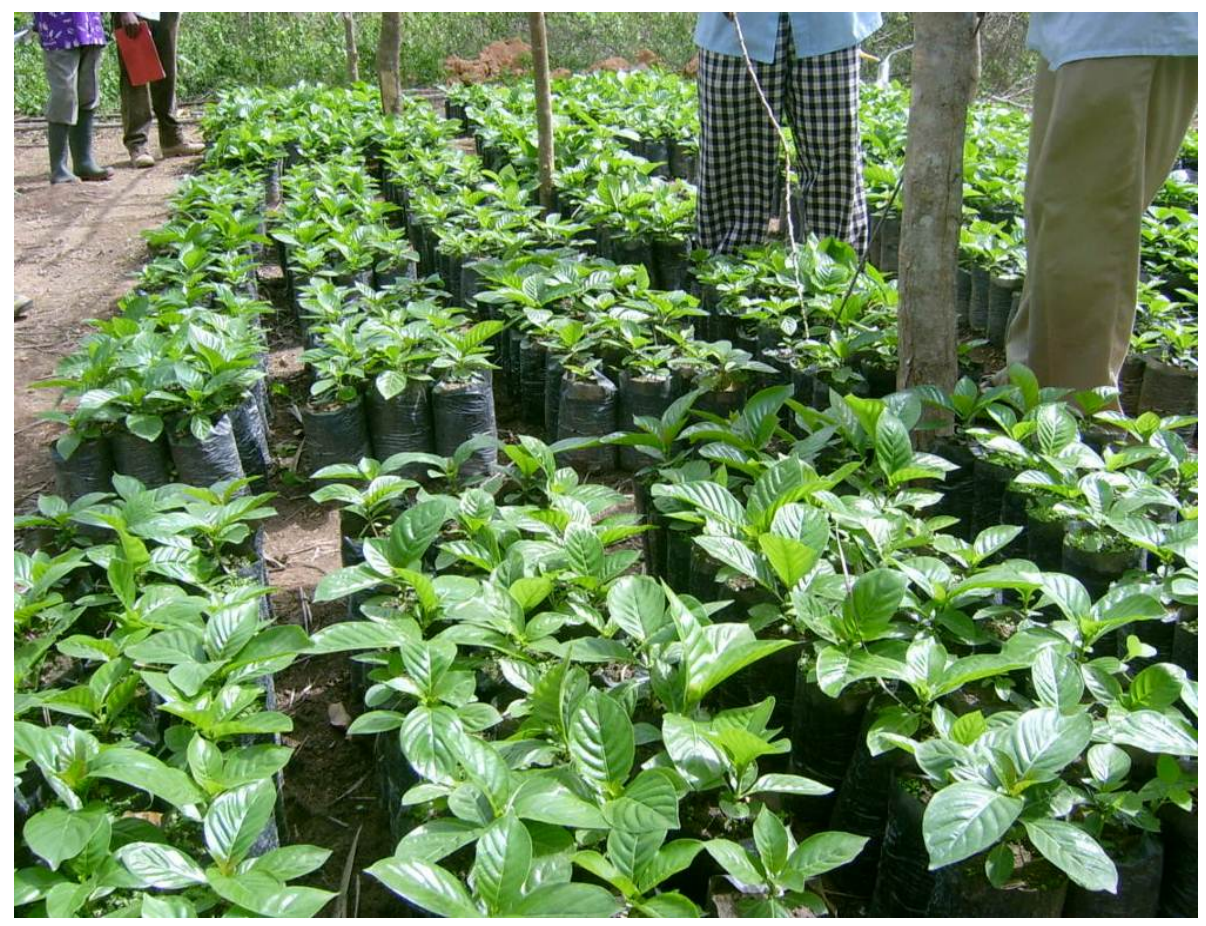

Photo 1. Three months Nursery of Nd. 
individuals. During each measurement campaign, two parcels of the same block were randomly selected and all the plants were measured. The plots of Tomégbé are subject to a minimum maintenance consisting of a single weeding every 6 months.

The experiment carried out at Tomégbé was replicated at Koudassi in a contrasting ecological area (Guinea savannah, low rainfall measured at $1072.5 \mathrm{~mm} /$ year in average, mean temperature of $27^{\circ} \mathrm{C}$, tropical ferruginous soils). In this station, only two randomized blocks consisting of 20 plots were tested by replacing the Ts and Ga by teak Tectona grandis (Tg).

In addition, plants were offered to private farmers in different localities sometimes with contrasting ecology (Figure 1): forest zone at Anonoé $\left(7^{\circ} 33^{\prime} 37^{\prime \prime} \mathrm{N}, 0^{\circ} 36^{\prime} 10^{\prime \prime E}\right.$, rainfall $1500 \mathrm{~mm} /$ year, ferralitic soil) and Ounabè $\left(7^{\circ} 34^{\prime} 00^{\prime \prime} \mathrm{N}, 0^{\circ} 59^{\prime} 00 " \mathrm{E}\right.$, rainfall $1400 \mathrm{~mm} /$ year, ferrallitic soil); in the guinea savannah at Kougnohou $\left(7^{\circ} 40^{\prime} 00^{\prime \prime} \mathrm{N}\right.$, $0^{\circ} 48$ '00"E, rainfall $1350 \mathrm{~mm} /$ year, tropical ferruginous soils), in extensive agriculture area of the coastal plain in the southern Togo at Aklakou $\left(6^{\circ} 2^{\prime} 00^{\prime \prime} \mathrm{N}, 1^{\circ} 43^{\prime} 00^{\prime \prime E}\right.$ characterized by low ferrallitic soil, fallow-crops, rainfall $1000 \mathrm{~mm} /$ year). Among those private farmers, only the average growth of Nd plants after 18 months experience was measured. The plots of the private farmers are regularly weeded because the plantations are carried out in a taungya system that is implemented by combining $\mathrm{Nd}$ with food crops. The spacings between the trees vary (Table 1).

To complete the knowledge on the growth of Nd in the Litimé, the testimonies of the populations on the approximate age of the coppices after felling the trees were collected. In addition, a few private parcels within the study zone were sampled and visited to complete the information on the growth of the tree.

\subsubsection{Data Processing and Analysis}

The density of trees in natural living communities was assessed by number of plants per hectare for trees with $\mathrm{dbh} \geq 10 \mathrm{~cm}$. Basal area of trees was calculated from the relationship $G=\sum \pi D^{2} / 4\left(\mathrm{G} \mathrm{m} \mathrm{m}^{2} / \mathrm{ha}\right.$, D the diameter of the trees). The spatial distribution of trees and the Nd ecological affinities have been known by entering the coordinates of the trees in a Geographical Information System (GIS) (MpInfo 7.0). The distances between individuals were calculated and the averages compared by ANOVA tests using the Minitab software. The ANOVA test is also used to compare differences in growth between the plants measured during different experimental treatments. The distribution of trees per diameter class was shown by means of graphs fitted to mathematical functions. The metric system relationship between dbh and the total height or the trunk height is an indicator of tree growth. It was expressed by a logarithmic regression equation $Y=a * \operatorname{Ln}(X)+b \quad(Y=$ height, $X=$ diameter at 1.30 ground level, a and $b$ are constants). Trees whose actual ages are known, because planted or felled at periods known by the local population and that produced coppices later on made it possible to adjust a regression line to gauge the $\mathrm{Nd}$ growth in time and make predictions on its logging period. Thus, a metric system function of logarithmic type between the age and the dbh or the height is more appropriate to undertake these forecasts [13] [14].

\section{Results}

\subsection{Distribution of Nd in Natural Forest}

The species grows on all geological (Figure 2) and topographic (Figure 3) substrates, showing its capacity to adapt to different environments. It is found in different topographic positions including flat grounds, top of hill-

Table 1. Experimental station throughout Togo.

\begin{tabular}{cccc}
\hline Station & Latitude & Longitude & Tree spacing (m) \\
Aklakou & $6^{\circ} 2^{\prime} 00^{\prime \prime}$ & $1^{\circ} 43^{\prime} 00^{\prime \prime}$ & $5 \times 5$ \\
Anonoè Nursery & $7^{\circ} 33^{\prime} 37^{\prime \prime}$ & $0^{\circ} 36^{\prime} 10^{\prime \prime}$ & $0^{\circ} 36^{\prime} 10^{\prime \prime}$ \\
Anonoè Village & $7^{\circ} 33^{\prime} 37^{\prime \prime}$ & $0^{\circ} 52^{\prime} 00^{\prime \prime}$ & $2 \times 3$ \\
Koudassi & $6^{\circ} 37^{\prime} 00^{\prime \prime}$ & $0^{\circ} 48^{\prime} 00^{\prime \prime}$ & $2.90 \times 3.20$ \\
Kougnohou & $7^{\circ} 40^{\prime} 00^{\prime \prime}$ & $0^{\circ} 59^{\prime} 00^{\prime \prime}$ & $2 \times 3$ \\
Ounabè & $7^{\circ} 34^{\prime} 00^{\prime \prime}$ & $0^{\circ} 36^{\prime} 14^{\prime \prime}$ & $2 \times 3$ \\
Tomégbé & $7^{\circ} 30^{\prime} 36^{\prime \prime}$ & & \\
\hline
\end{tabular}




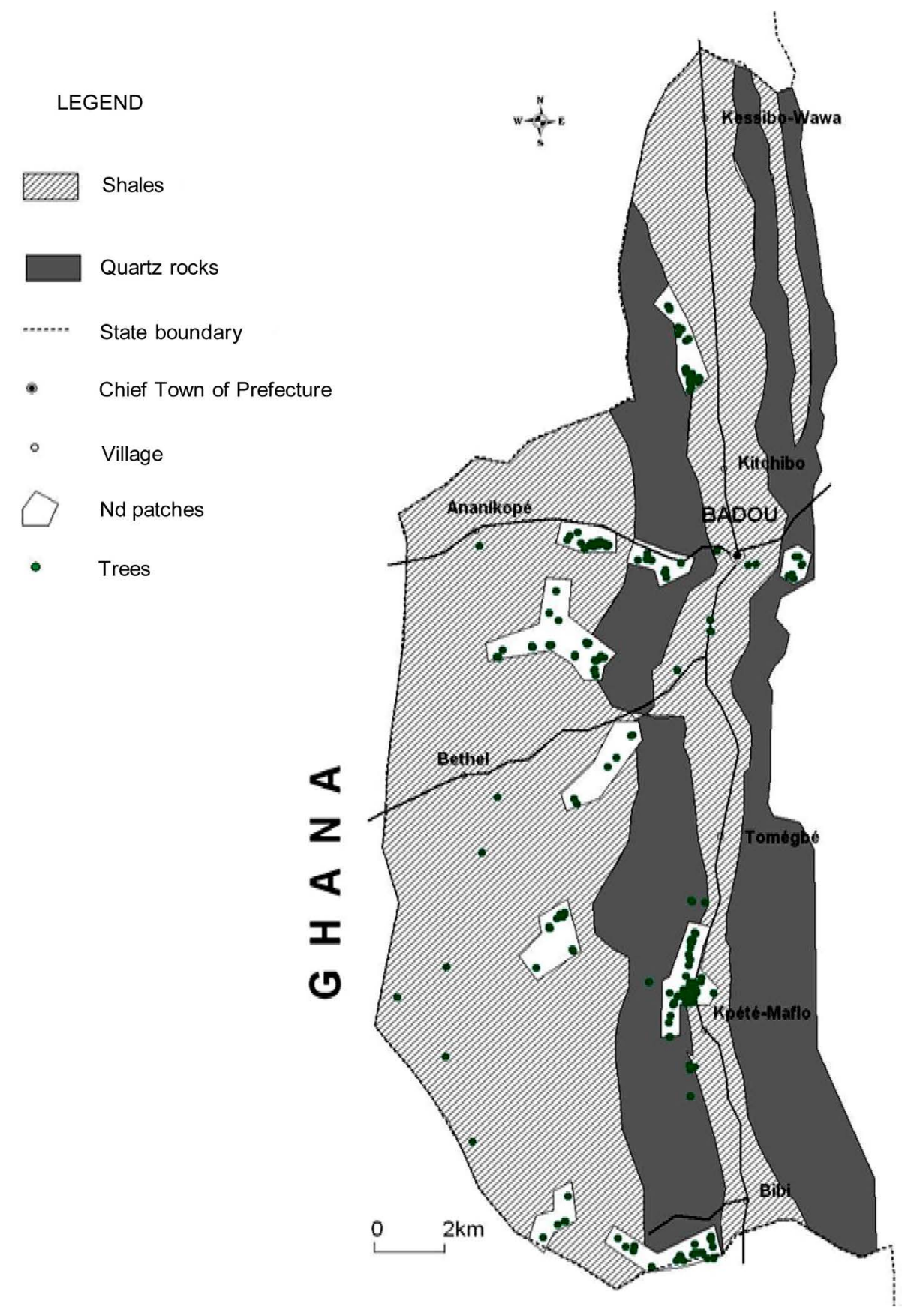

Figure 2. Distribution of Nd in relation to the geologic substratum of Litimé (After the geologic map-Sheet of Atakpamé: 1/200 000).

side, on the banks of rivers or in deep valleys. Yet, it seems better adapted to low-and mid-hillside (Figure 4). Some trees grow in the mountains (average altitude of $450 \mathrm{~m}$ ) following the embankment of the talwegs on slopes up to $50 \%$. No tree has been identified in the high hill at $850 \mathrm{~m}$ altitude. The species grows well on different types of soils (ferrallitic soils, tropical ferruginous soils, hydromorphic soils and less developed soils). It is more abundant on less developed soils on slopes of mountains where $58.5 \%$ of trees were identified and on scrap iron soils (32.8\% of trees). The remaining trees have been identified on ferruginous soils (8.2\%) and only 0.5\% on hydromorphic soils (Figure 5). On these different soil substrates, Nd occurs, preferably, on loamy soils and avoids long inundated stations during the year. $\mathrm{Nd}$ also likes the termite, $19 \%$ of the trees were identified 


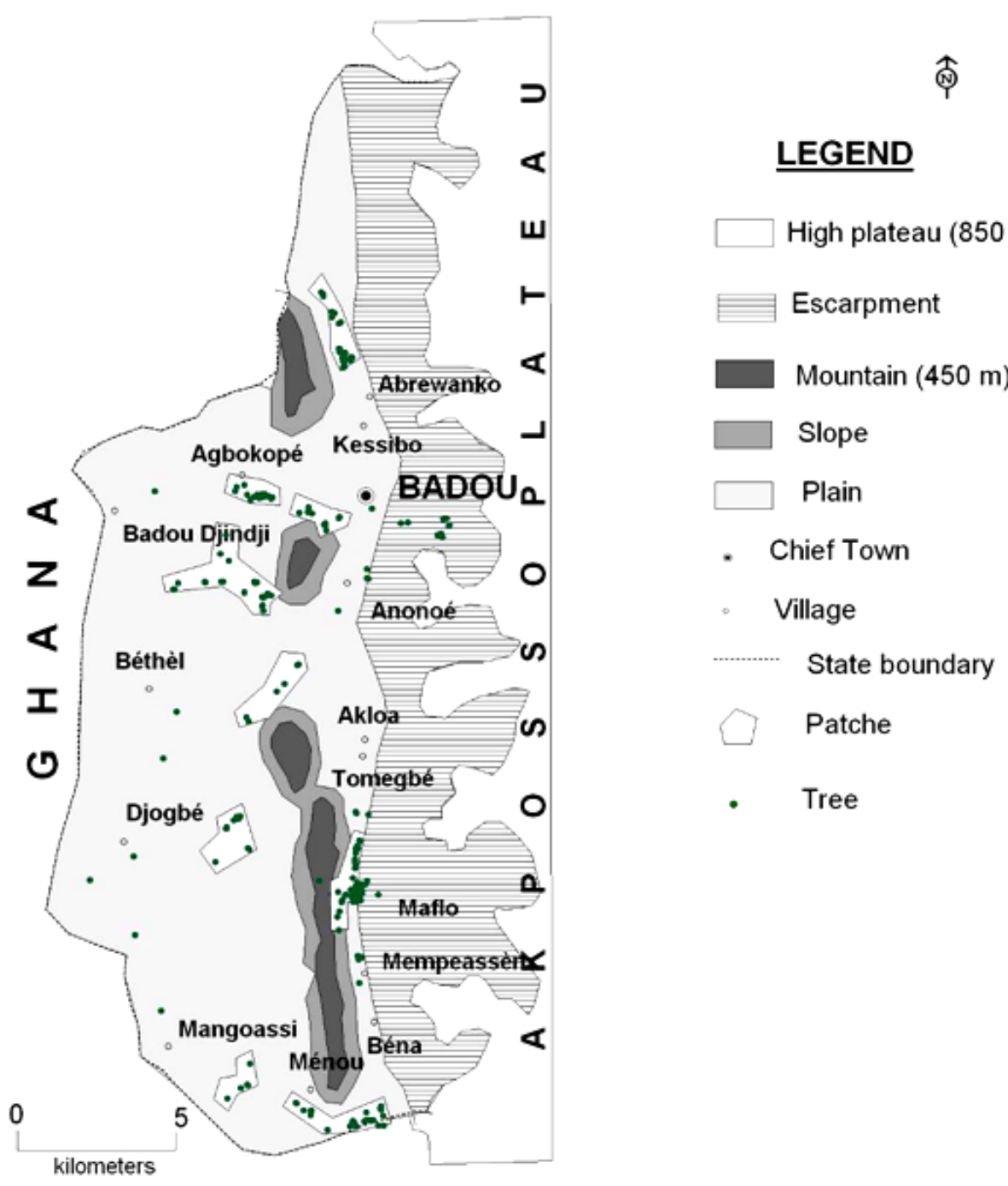

Figure 3. Distribution of $\mathrm{Nd}$ in relation to the topography of Litimé (After the topographic map of Elavagnon 1/50 000: Sheet of Badou NB-31-XIX-4a.

there.

In natural stand, Nd has a distribution in patches. A patch is a grouping of individuals defining an average surface of $155 \pm 120$ ha. These patches contain in average 19 trees (86 individuals in maximum and in minimum 7). The distance between two patches is in average $3.5 \pm 1.5 \mathrm{~km}$. Few individuals remain isolated. Approximately 2000 ha sampled, 10 patches were identified (Figure 3, Figure 4, Figure 5). The average distances between trees are from 82 to $96 \mathrm{~m}$. The difference between the average distances between trees is not significant $\left(F_{3,287}=0.21, P=0.890\right)$. Based on the average distance between two trees, the patches were demarcated by connecting a distant polygon line of $100 \mathrm{~m}$ from peripheral mature trees that describe the outline of trees that form a patch.

\subsection{Structure of Nd Stands}

The total number of identified individuals is 305 trees, including stumps of trees felled. The density of trees (dbh $\geq 10 \mathrm{~cm}$ ) is of 0.15 tree $/$ ha. The average diameter of trees is $38.16 \mathrm{~cm}$. The distribution per class of tree diameter shows an "L" model distribution, indicating steady dynamic populations of $\mathrm{Nd}$ in the Litimé (Figure 6). This distribution fits better to a polygonal function of degree 2 whose equation is: $Y=0.00 X^{2}-0.003 X+0.016$ with $\mathrm{R}^{2}=0.92$. 


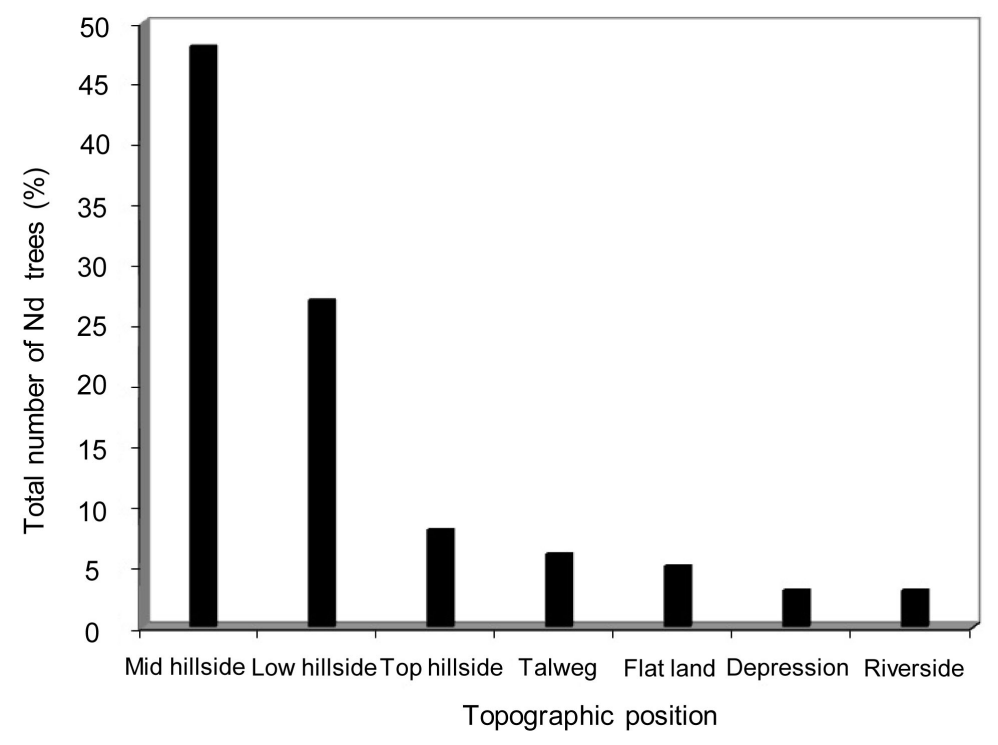

Figure 4. Topographic preference of Nd in Litimé

The basal area is $0.9410^{-2} \mathrm{~m}^{2} / \mathrm{ha}$. The trend curve which expresses better the relationships between the basal area and the diameter classes is an exponential function whose equation is: $Y=0.62 e^{0.21 X}$ with $\mathrm{R}^{2}=0.93$, showing that most of the surface areas are combined with the large diameter classes (Figure 7).

The average total height of the population is $15.66 \mathrm{~m}$ and the average merchantable height is $10.58 \mathrm{~m}$. The allometric growth relationships between these two heights and the dbh match better by a logarithmic function whose equations are respectively: $Y_{h t}=9 L N(X)-14.45$ with $\mathrm{R}^{2}=0.65$ and $Y_{h t}=8.39 L N(X)-17.91$ with $\mathrm{R}^{2}=0.56$ (Figure 8). These two correlations fit very well with dbh less than $60 \mathrm{~cm}$ and are very random beyond this value. These curves show that in silviculture, it is possible to forecast the stands growth up to $60 \mathrm{~cm}$ in diameter, but beyond that, the growth of stands depends more on environmental factors.

\subsection{Regeneration, Growth and Adaptation}

The trees from seedling represent approximately $28 \%$. The preferred regeneration method of $\mathrm{Nd}$ is the coppices from stump; Nd shoots considerably, $61 \%$ felled tree produce coppices and only $11 \%$ failed to shoot after use. The average number of coppices is 4 stems per tree. These coppices are quite strong, which may have diameters ranging from 9 to $18 \mathrm{~cm}$, with a merchantable height reaching $5.32 \mathrm{~m}$ and an average total height of $6.01 \mathrm{~m}$.

Despite the abundance of fruits produced by trees every year, the regeneration by seed is very low. Under the mother-trees or far from them, no future stem $(\mathrm{dbh} \leq 10 \mathrm{~cm})$ had been identified on the field, apart from trees planted by some farmers in their fields. However, the tests of germination in situ have been very successful and made it possible to obtain more than 7000 plants between 2006 and 2008. These plants, placed in the ground, have provided important information on the Nd silviculture, precisely, the appropriate growing conditions, the gaps and the ecological environment. At the experimental station at Tomégbé in Litimé, Nd reached a maximum average height of $141.22 \pm 26.06 \mathrm{~cm}, 18$ months after planting (Figure 9). The growth depends on whether Nd is in monoculture or associated with other species. In young plantations of 6 months, Nd monoculture does not show significant difference in growth compared to the growth of $\mathrm{Nd}+\mathrm{Ts}, \mathrm{Nd}+\mathrm{Ga}$, or $\mathrm{Nd}+\mathrm{Ts}+\mathrm{Ga}(\mathrm{F} 3,106=$ $1.13, \mathrm{P}=0.342)$. Within a year, $\mathrm{Nd}$ has a significant growth when it is associated with $\mathrm{Ga}$ or $\mathrm{Ts}+\mathrm{Ga},(\mathrm{F} 3,89=$ $3.43, \mathrm{P}=0.020$ ) compared to when in monoculture or associated with a Ts which is a competitor tree. After a year and a half, the best growth of $\mathrm{Nd}$ is achieved when it is in combination with Ga; the growth is significantly higher than the other exploitation (F3, $90=2.76, \mathrm{P}=0047$ ) (Table 2). Figure 9 makes it possible to notice at this age, Ts inhibits the growth of Nd when combined. This can be explained by the competition established between the two trees (Nd and Ts). In silviculture, it is better to plant Nd in combination with a dominated species (Ga) rather than a species that has the same anti solar requirements (Ts). On the site of Tomégbé, the mortality rate following the experiment is $6.66 \%$. 


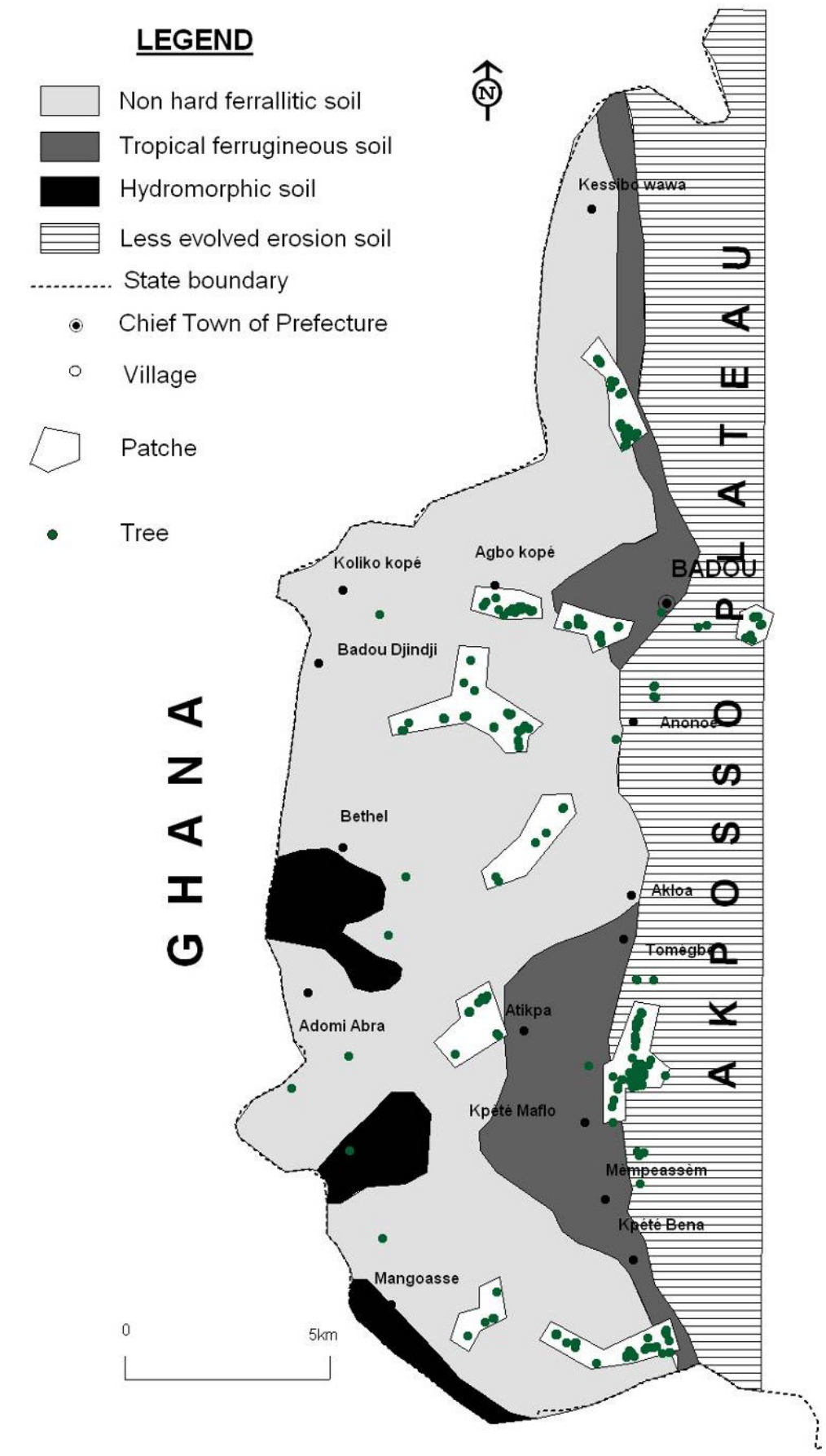

Figure 5. Distribution of Nd in relation of the soils of Litimé (After Lamouroux, 1969).

In guinea savannah, the growth is slower compared to Tomégbé, the maximum average height being $109.37 \pm$ $39.14 \mathrm{~cm}$. The best growth is achieved when Nd is associated with a plant (the case of Tg at Koudassi) that can help protect it against high and long solar luminosity (Figure 10). This difference in growth that is not significant at 6 months $\left(F_{1,116}=0.64 ; \mathrm{P}=0.424\right)$, becomes significant at 12 months $\left(F_{1,31}=7.20 ; \mathrm{P}=0.012\right)$ and even more at 18 months $\left(F_{1,47}=5.70, P=0.021\right)$ (Table 3$)$. However, the results show that Nd adapts itself very poorly to areas of guinea savannah, and the mortality is very high and equal to $66.48 \%$.

The planting of Nd in different localities by private growers to whom plants have been given, makes it possi- 


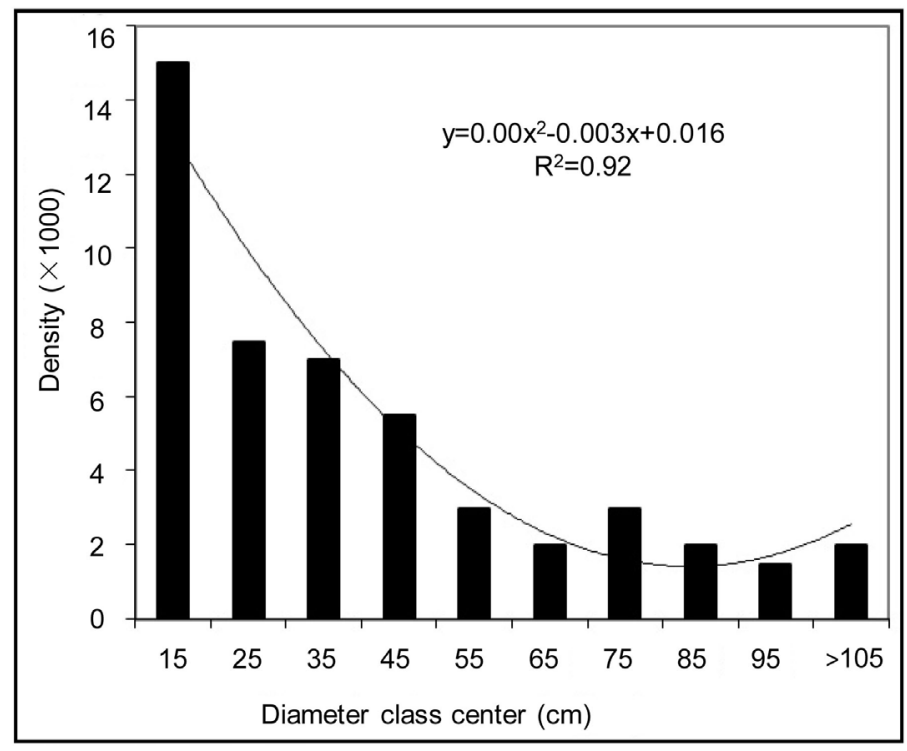

Figure 6. Distribution of Nd trees per class of diameter.

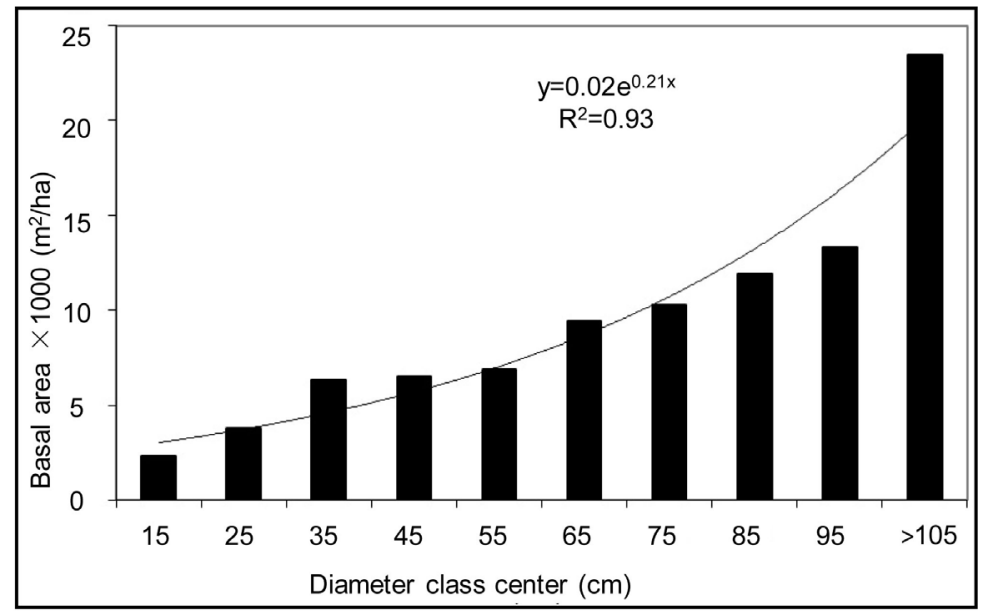

Figure 7. Distribution of basal area per class of diameter.

ble for a better understanding of the temperance and the ecology of the species but also of the impact of maintenance on the trees. Anonoé and Tomégbé are Litimé localities where Nd is an exclusive species. However Anonoè trees, after a year and half of monitoring, have an average height significantly higher than the station of Tomégbé $\left(\mathrm{F}_{6}, 75=29.57, \mathrm{P}=10^{-3}\right)$. This difference in growth is related to the maintenance of plots, the plants of Anonoè are planted using a taungya method with regular maintenance while the maintenance at Tomégbé is carried out once every 6 months. Ounabè is a station located in forest area as Litimé but in the highlands. Plants have a growth as important as that of plants of Litimé, showing therefore that Nd can adapt easily in the whole forest zone in Togo. Aklakou is a station in the far south, but also records a very important growth, evidence that the plant can be relocated outside the forest area when the climate and soil conditions are met (rainy seasons with a good reparation and ferrallitic soil). On the other hand, Kougnohou is far well in savannah area included in the forest zone. Consequently, trees are less developed. In the savannah zone, at Kougnohou as well as at Koudassi, the soil and climatic conditions are not conducive to the growth of the plant (Figure 11).

The results also show that at this stage of growth, the spacing has no influence on the growth of trees. Between the stations of Aklakou $(5 \mathrm{~m} \times 5 \mathrm{~m})$, Anonoè $(2 \mathrm{~m} \times 3 \mathrm{~m}$ or $3 \mathrm{~m} \times 3 \mathrm{~m})$ or even Ounabè $(2 \mathrm{~m} \times 3 \mathrm{~m})$, the difference in the tree growth after 18 months of follow-up is not significant. This is similar to the savannah stations of Koudassi $(2 \times 3)$ or Kougnohou $(2.90 \times 3.20)$, the difference in growth is not significant (Figure 11). 


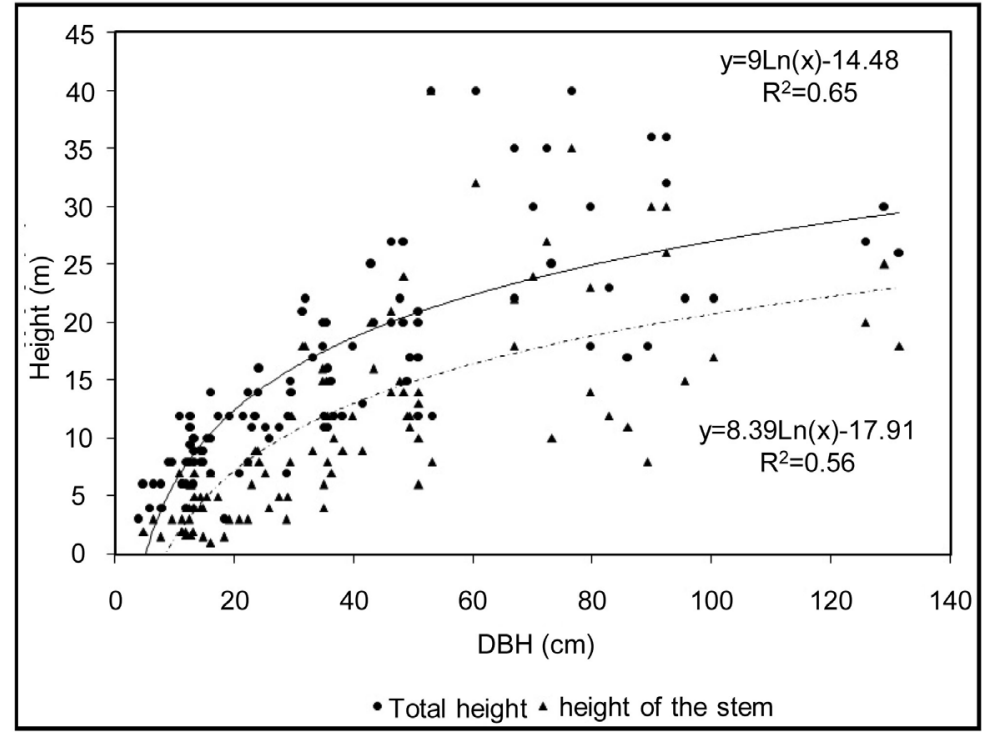

Figure 8. Correlation between heights and diameter.

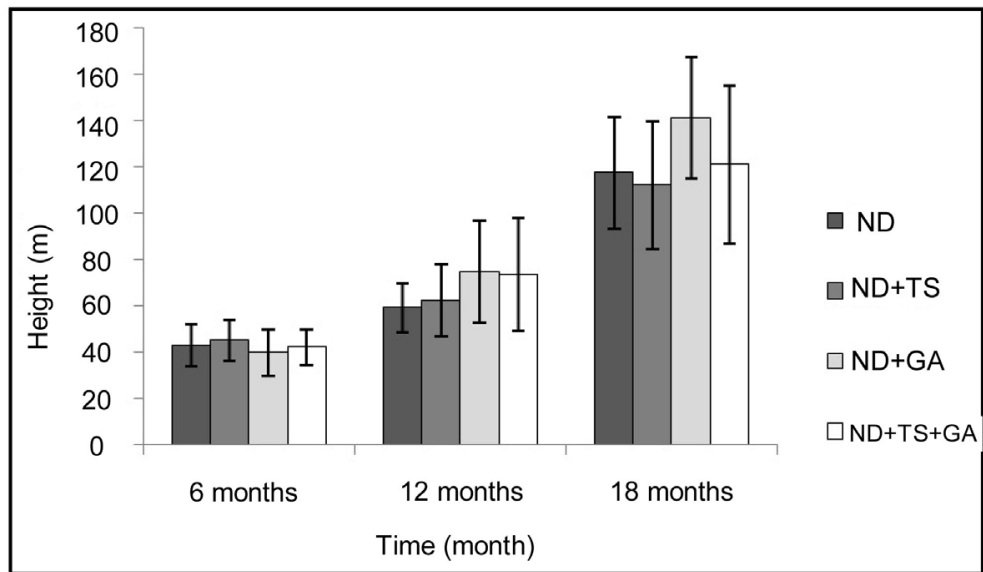

Figure 9. Evolution of the growth of Nd in monoculture or in association at Tomégbé (Nd: Nauclea diderrichii, Ts: Terminalia superba, Ga: Garcinia afzelii).

Table 2. Test of Fisher comparing the growth of Nd in the station of Tomégbé.

\begin{tabular}{cccc}
\hline \multirow{2}{*}{ Randomized block } & \multicolumn{3}{c}{ Average height $(\mathbf{c m})$} \\
\cline { 2 - 4 } & $\mathbf{6}$ months & $\mathbf{1 2}$ months & $\mathbf{1 8}$ months \\
$\mathrm{nyd}$ & $43.63 \pm 9.17$ & $59.28 \pm 10.49$ & $117.41 \pm 24.11$ \\
$\mathrm{Nd}+\mathrm{Ts}$ & $45.55 \pm 8.78$ & $62.59 \pm 15.58$ & $112.21 \pm 27.40$ \\
$\mathrm{Nd}+\mathrm{Ga}$ & $40.79 \pm 10.04$ & $74.83 \pm 21.82^{\mathrm{ab}}$ & $141.22 \pm 26.06^{\mathrm{ab}}$ \\
$\mathrm{Nd}+\mathrm{Ts}+\mathrm{Ga}$ & $42.33 \pm 7.33$ & $73.63 \pm 24.68^{\mathrm{ab}}$ & $120.94 \pm 33.97$ \\
Coefficient of Fisher & $\mathrm{F}_{3,106}=1.13$ & $\mathrm{~F}_{3,89}=1.13$ & $\mathrm{~F}_{3,90}=1.13$ \\
Probability & $\mathrm{P}=0.342$ & $\mathrm{P}=0.020$ & $\mathrm{P}=0.047$ \\
\hline
\end{tabular}

Nd: Nauclea diderrichii, Ts: Terminalia superba, Ga: Garcinia afzelii; ${ }^{a}$ significant growth comparing to the one of Nd pure; ${ }^{b}$ significant growth comparing to the one of $\mathrm{Nd}+\mathrm{Ts}$.

Based on a few private plots planted by local populations in the Litimé and which are older than those planted in the framework of this project but also the age of the coppices obtained from the populations, it has been pos- 
Table 3. Test of Fisher comparing the growth of Nd in the station of Koudassi.

\begin{tabular}{cccc}
\hline Randomized block & \multicolumn{3}{c}{ Average Height (cm) } \\
\cline { 2 - 4 } & 6 months & 12 months & 18 months \\
Nd & $35.79 \pm 9.25$ & $34.94 \pm 13.39$ & $82.10 \pm 38.42$ \\
Nd + Tg & $37.43 \pm 9.43$ & $50.56 \pm 19.06^{\mathrm{d}}$ & $109.37 \pm 39.14^{\mathrm{d}}$ \\
Coefficient of Fisher & $\mathrm{F}_{1,116}=0.64$ & $\mathrm{~F}_{1.31}=7.20$ & $\mathrm{~F}_{1,47}=5.70$ \\
Probability & $\mathrm{P}=0.424$ & $\mathrm{P}=0.012$ & $\mathrm{P}=0.021$ \\
\hline
\end{tabular}

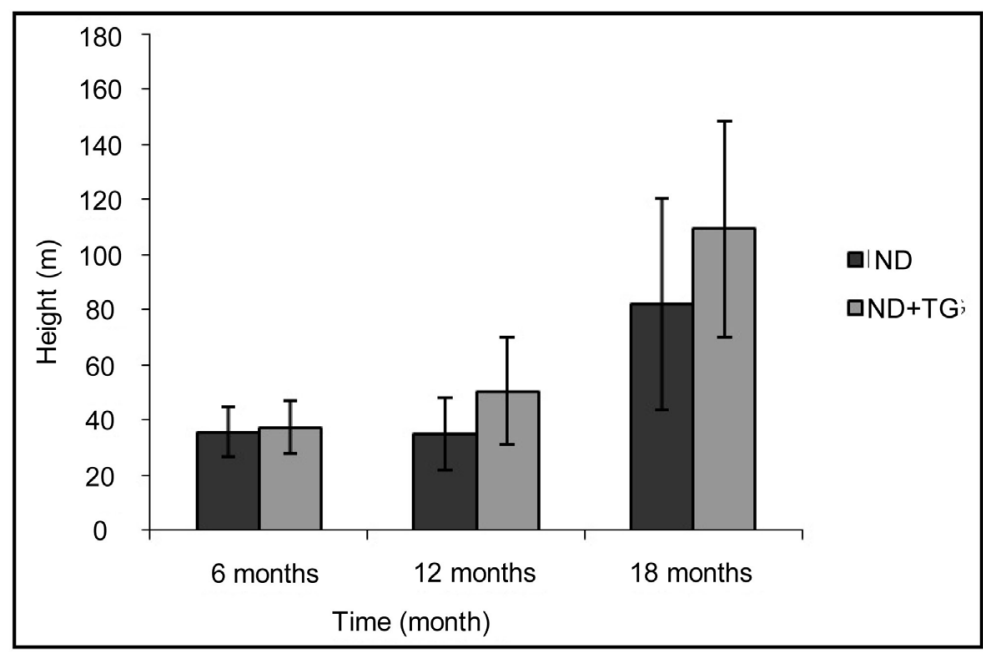

Figure 10. Evolution of the growth of Nd in monoculture or in association at Koudassi (Nd: Nauclea diderrichii, Tg: Tectona grandis).

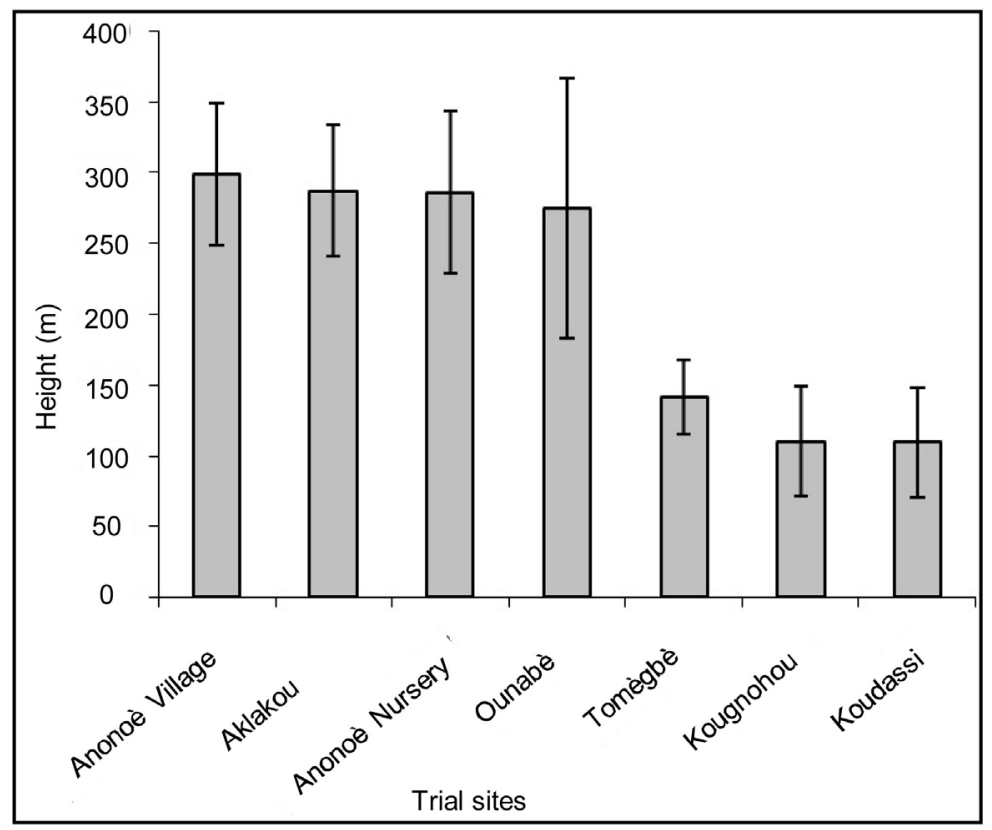

Figure 11. Growth of Nd in different ecological areas.

sible to establish a correlation between the age and the diameter. The model that expresses this relationship of growth is a logarithmic function of equation $Y=6.10 L N(X)+5$ with $\mathrm{R}^{2}=0.57$ (Figure 12). The curve indicates that populations are able to mention the dates at which the trees have been exploited when the latter are 


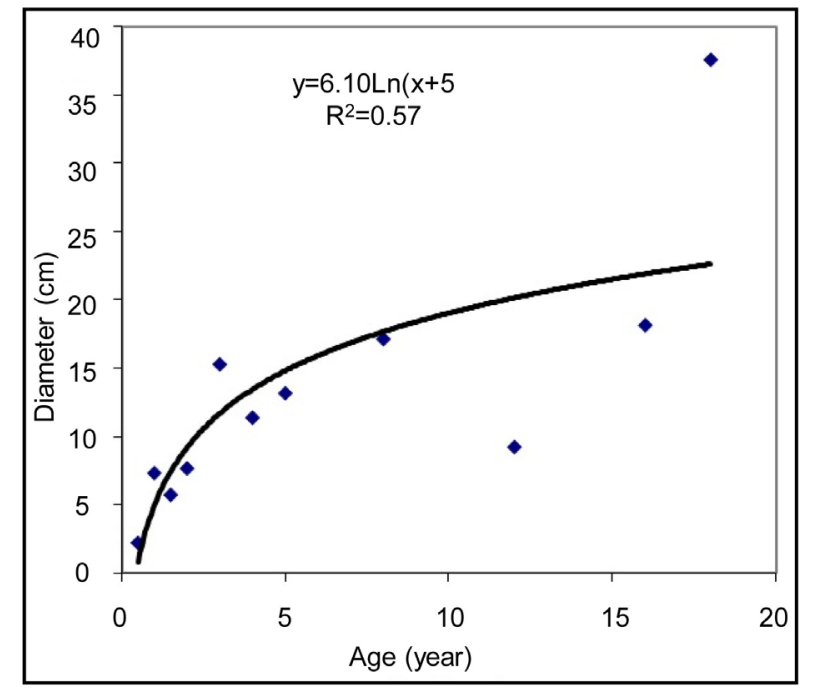

Figure 12. Evolution of the diameter in relationship with the age.

below 10 years. Beyond 10 years, the exploitation ages given are very uncertain. These values do not allow to set the age of exploitation of trees in natural forest at the present state of knowledge. However, Figure 12 indicates that around 10 years, $\mathrm{Nd}$ plantations can reach $17 \mathrm{~cm}$ in diameter, i.e. an increase of about $1.7 \mathrm{~cm}$ per year. At this pace of growth, it is possible to produce $\mathrm{Nd}$ poles at 16 years, corresponding to an average diameter of $27 \mathrm{~cm}$.

\section{Discussion}

This study made it possible to know the parameters needed to control the silviculture of Nd. One of these parameters is the spacing between the trees. The results demonstrate that a spacing of $2 \mathrm{~m} \times 3 \mathrm{~m}$ to $5 \mathrm{~m} \times 5 \mathrm{~m}$ has no incidence on the early growth of Nd. However, the average distance between trees $(\mathrm{dbh} \geq 10 \mathrm{~cm})$ in natural stands is about a hundred meters. This is an important indicator to be considered in silviculture in that the trees at the end of the rotation should be sufficiently spaced. The tree grows according to the architectural pattern of Massart [17], with very large branches, corresponding to 75 to $86 \%$ of the total weight of the tree [14]. Space is needed to foster the blooming of these branches and the normal growth of trees. The pruning of these powerful branches is achieved naturally [18]-[20], providing the tree with perfectly cylindrical trunk at the rotation end. However, in plantation, such results are only possible when the tree is planted at a high initial density as that advocated in this study. In Nigeria, [14] indicates that the Nd density at 5 years in plantation is 625 trees/ha at interval of $4 \mathrm{~m} \mathrm{x} 4 \mathrm{~m}$ and that this density is reduced to 496 trees/ha when the trees reach 30 years.

The growth of the tree in diameter is estimated at $1.7 \mathrm{~cm} /$ year based on data recorded on the field (for a period of 18 months). This value is similar to that given by [14] who thinks that the dbh of Nd in plantation in Nigeria varies from 9.0 to $23.6 \mathrm{~cm}$ for trees aged between 5 and 30 years and whose annual growth would be between 1 and $1.8 \mathrm{~cm} /$ year. The author states that growth diameter decreases between 5 and 30 years but that stabilization is observed between 24 and 30 years. Even if this growth rate is low, compared with the usual exotic species such as Gmelina arborea Roxb., Acacia mangium Willd. Pinus caribea Morelet [21]-[26], it is equivalent to that of the local species used since then in forest plantation as Terminalia spp, Khaya spp, Lophira alata van Thiegh. ex Keay and even Cedrela odorata L. and Tectona grandis L. f. which are exotic species widely used in Africa for reforestation [19]-[27].

The study shows that Nd is in patch in the forest of Litimé. Other authors have reported earlier this distribution mode in the African forest [28] [29]. The spatial distribution of forest species has been the subject of many studies in the Guiana rainforest [30]. These studies revealed that some forest species have distributions different from random distributions that occur in small and medium aggregates (e.g. Dicorynia guianensis Amsh.) or even large patches (case of Vouacapoua americana JB Aublet.). This last distribution is suitable for Nd. However, unlike the relatively wild landscape of Guyana's forests, the Litimé forests host a high-density population 
whose daily activity is agriculture and forest production that obviously limit the Nd spatial distribution. In African tropical forest, other species also have distributions in large patche, as is the case of Okoume (Aucoumea klaineana Pierre) or Gilbertiodendron dewevrei (De Wild) J. Leonard. The same applies to Isoberlinia stands in sudanian savannahs. The dynamics of space colonization is often linked to the seeds' dispersal mode of or the soil gradient that creates density variations.

In the Litimé, the Nd natural stands have a "L" demographic structure, i.e., they are distributed so rapidly in a decreasing manner from the small diameters to the maximum diameters. This distribution relates to the regeneration mode by coppices of individuals. The tree is highly valued (61\% of trees recorded have been already exploited) and each stump produces an average of 4 coppices. The abundance of coppices accounts for this "L" distribution of Nd stands. Contrary to this species capacity to produce stumps, the regeneration by seeds under or near the mother-trees seems very low. However, the field experiments provide interesting results for the development of silviculture. It matches better to the taungya method in the forest zone and in sites where rainfall is satisfactory.

Through the results of the development of the growth of Nd in monoculture or in association with other species (Ts and Ga), it appears that Ts inhibits the growth of $\mathrm{Nd}$ when combined. This can be explained by the competition established between the two trees (Nd and Ts). Indeed, Nd and Ts are two species defined as "socially dominant species" [31]. For their establishment, these species require light and enough space otherwise they disappear quickly. However, Ts is a sun-loving species of the first order which requires more light for its growth than that of Nd. For this reason, when the two species are combined on the same plot, Ts grows in height more than Nd reflecting a growth inhibition of Nd. In silviculture, it is better to plant $\mathrm{Nd}$ in combination with a dominated species $(\mathrm{Ga})$ rather than a species that has the same anti solar requirements (Ts).

\section{Conclusions}

This preliminary study gives the state of things on the Nd natural living communities in Litimé semi-deciduous forest. It also provides important information on the ecology, the structure and the silviculture of Nd. Indeed, the growth patterns developed are important factors for predicting the tree growth, its usability and planning the silvicultural interventions, more precisely the thinning operations. The regeneration mode by coppices is a considerable advantage for the species in plantation just like teak. The experiments carried out make it possible to consider the forest area as the preferred Nd habitat. At 18 months, the species can reach $3 \mathrm{~m}$ in height. At 16 years, it is possible to obtain poles of about $27 \mathrm{~cm}$ in diameter. A complete rotation could be envisaged at 50 years with logs presenting highly developed heartwood. In view of its outreach, the main lessons learned from this study are structured as follows:

- Nd adapts itself to different ecological environments in forest zone but the savannahs where the dry season is long are not conducive;

- the average distance between dbh trees $>10 \mathrm{~cm}$ in natural stands is about $100 \mathrm{~m}$. This distance must be taken into account in the species silviculture particularly for the natural regeneration;

- the plantations can be installed at very close intervals from the beginning ( $2 \mathrm{~m} \times 3 \mathrm{~m}$ to $5 \mathrm{~m} \times 5 \mathrm{~m}$, followed by a first very strong thinning to aerate the stand and foster the growth;

- the growth patterns developed helps to predict the growth of trees and the silvicultural interventions up to $\mathrm{dbh}=60 \mathrm{~cm}$ at least. Beyond this dbh, the growth of trees is uncertain and would depend on environmental factors;

- trees shoot but the natural regeneration by seed is very deficient;

- the stumps can provide in average 4 shoots, much like teak after rotation;

- the determination of the age of exploitation requires further studies.

\section{Acknowledgments}

Sincere gratitude to African Academy of Sciences (AAS) and the African Network of Forestry Research (AFORNET) for their financial support.

\section{References}

[1] Grainger, A. (1986) Deforestation and Progress in Afforestation in Africa. International Tree Crops Journal, 4, 33-48. http://dx.doi.org/10.1080/01435698.1987.9752807 
[2] Roby, A.J. (1991) The Supply of Forest Product in Nigeria. TAFP Nigeria. First Steps Sector Analysis: Annex 5. Overseas Development Administration, UK.

[3] World Rainforest Movement (WRM) (1999) Africa: Background Document. In Workshop on Underlying Causes of Deforestation and Forest Degradation, 18-22 January 1999, Costa Rica.

[4] Ern, H. (1979) Die Végétation Togos. Gliederrung, Erhaltung, Willdenowia, 9, 295-312.

[5] Brunel, J.F., Scholz, H. and Hiepko, P. (1984) Flore Analytique du TOGO. Phanérogames, GTZ, Eschorn, 751.

[6] Akpagana, K. (1992) Les forêts denses humides des monts du Togo et Agou (République du Togo). Bulletin du Museum National d'Histoire Naturelle, Paris, 4è sér., 14, Section B, Adansonia, 109-172.

[7] Vanpraet, C.L. (1980) Projet pilote sur la surveillance continue de la couverture végétale et étude de ces modifications, Togo. FAO/ PNUE, Rome

[8] Afidégnon, D., Carayon, J.L., Fromard, F., Lacaze, D., Guelly, A. K., Kokou, K., Woégan, Y.A. and Batawila, K. (2002) Carte de la végétation du Togo au 1/50.000è. Université Paul Sabatier de Toulouse et Université de Lomé

[9] Adjossou, K. (2004) Diversité floristique des forêts riveraines de la zone écologique IV du Togo. Mémoire de DEA, Université de Lomé.

[10] Myers, N., Mittermeier, R.A., Mittermeier, C.G., da Fonseca, G.A.B. and Kent, J. (2000) Biodiversity Hotspot for Conservation Priorities. Nuture, 403, 853-858. http://dx.doi.org/10.1038/35002501

[11] FAO (1981) Tropical Forest Resources Assessment. Forest Resources of Tropical Africa, part II. UN 32/6.1301-78-04. Technical Report No. 2, FAO, Rome.

[12] Irvine, F.R. (1961) Woody plants of Ghana. Oxford University Press, London.

[13] Onyekwelu, J.C. (2001) Growth Characteristics and Management Scenarios for Plantation-Grown Gmelina arborea and Nauclea diderrichii in South-Western Nigeria. Hieronymus Verlag, Munich, 196.

[14] Onyekwelu, J.C. (2007) Growth, Biomas Yield and Biomas Functions for Plantation-Grown Nauclea diderrichii (de Wild) in the Humid Tropical Rainforest Zone of South-Western Nigeria. Bioresource Technology, 98, 2679-2686. http://dx.doi.org/10.1016/j.biortech.2006.09.023

[15] Papadakis, J. (1966) Enquête agro-écologique en Afrique Occidentale/Libéria, Côte d’Ivoire, Ghana, Togo, Dahomey, Nigéria/FAO, 43.

[16] Kouwamé, K. (2005) Evolution récente des reliques forestières à sous-bois cultivé et ses conséquences environnementales dans la plaine du Litimé (Sud-Ouest Togo). Mémoire de Maîtrise ès Lettres, option Géographie physique, 88.

[17] Oldeman, R.A.A. (1983) Tropical Rain Forest, Architecture, Sylvigenensis and Diversity. Special Publication Series of the Bristish Ecological Society No. 2., Blackwell Scientific Publications, 498.

[18] Keay, R.W.J. (1989) Trees of Nigeria. A Revised Version of “Nigerian Trees” (Keay et al., 1964). Clarendon Press, Oxford.

[19] Dupuy, D. and Mille, G. (1993) Timber plantations in the humid tropics of Africa. FAO Forestry Paper 98. FAO, Rome, 190.

[20] Onyekwelu, J.C. and Stimm, B. (2004) Nauclea diderrichii (De Wild) Merr, 1915. In: Schütt, P., Weisgerber, H., Lang, U., Roloff, A. and Stimm, B., Eds., Enzyklopädie der Holzgewächse-37, Erg. Lfg. Ecomed-Publisher, Munich, 12.

[21] Mok, C.K., Cheah, L.C. and Chan, Y.K. (1999) Site Management and Productivity of Acacia mangium in Humid Tropical Sumatra, Indonesia. In: Nambiar, et al., Eds., Proceedings of a Workshop on Site Management and Pro- ductivity in Tropical Plantation Forests, 88-94.

[22] FAO (2001) Mean Annual Volume Increment of Selected Industrial Forest Plantation Species by L. Ugalde \& O. Perez. Forest Plantation Thematic Papers, Working Paper FP/1, Forest Resources Division, FAO, 27.

[23] Onyekwelu, J.C. (2001) Growth, Biomas Yield and Biomas Functions for Plantation-Grown Nauclea diderrichii (de Wild) in the Humid Tropical Rainforest Zone of South-Western Nigeria. Bioresource Technology, 98, 2679-2686. http://dx.doi.org/10.1016/j.biortech.2006.09.023

[24] Swamy, S.L., Puri, S. and Singh, A.K. (2003) Growth, Biomass, Carbon Storage and Nutrient Distribution in Gmelina arborea Roxb. Stands on Red Lateritic Soils in Central India. Bioresource Technology, 90, 109-126. http://dx.doi.org/10.1016/S0960-8524(03)00120-2

[25] Evans, J. and Turnbull, J.W. (2004) Plantation Forestry in the Tropics. 3rd Edition, Oxford University Press, 467.

[26] RejÓn, L.A., Romero, J.L. (2004) Plantation of Gmelina arborea in Southern Mexico. New Forests, 28, $293-297$.

[27] Krishnapillay, B. (2000) Silviculture and Management of Teak Plantations. Unasylva, 51, 12.

[28] CTFT (Centre Technique Forestier Tropical) (1956) Bilinga. Bois et Forêts des Tropiques No. 47, 10-14. 
[29] CTFT (Centre Technique Forestier Tropical) (1999) Fiche botanique, forestière, industrielle et commerciale: Bilinga: fiche technique. Bois et Forêts des Tropiques No.160, 34-46.

[30] Forget, P.M. (1988) Dissémination et régénération naturelle de huit espèces d'arbres en forêts guyanaise. Thèse de 3è cycle, Université Pierre et Marie Curie, Paris, 245.

[31] Dupuy, B. (1998) Bases pour une sylviculture en forêt dense tropicale humide africaine, 328. 